de Direito Processual

\title{
A Natureza Jurisdicional da Jurisdição Voluntária: Uma Homenagem A J. J. Calmon de Passos
}

The Jurisdictional Nature of Voluntary Jurisdiction: A Tribute to J. J. Calmon de Passos.

Eraldo Ramos Tavares Júnior

'Centro Universitário UniRuv, Brasil

\section{Resumo}

Este trabalho tem como objetivo analisar a visão da jurisdição voluntária sustentada por J.J. Calmon de Passos ainda em 1957, quando publicou sua obra Da Jurisdição, em especial do problema relacionado à natureza jurídica, tema que, a despeito de antigo, ainda hoje é objeto de debates doutrinários.

Palavras-chave:Jurisdição voluntária; J.J. Calmon de Passos; Natureza jurídica

\begin{abstract}
This work aims to analyze the vision of voluntary jurisdiction supported by JJ Calmon de Passos even in 1957, when he published his work Da Jurisdição, in particular the problem related to legal nature, a theme that despite the old, is still the subject of debates today doctrinal.
\end{abstract}

Keywords: Voluntary jurisdiction; J.J. Calmon de Passos; Legal nature

\section{Introdução}

O presente trabalho foi elaborado diante da realização de congresso organizado pela Associação Norte Nordeste de Professores de Processo (“ANNEP”), nos dias 9, 10 e 11 de julho de 2020, em homenagem ao centenário de J.J. Calmon de Passos, jurista que deixou extensa contribuição para o estudo do Direito e marcou todos que o sucederam¹.

Em 1957, Calmon de Passos publicou sua obra Da Jurisdição², oportunidade em que sustentou a natureza jurisdicional da jurisdição voluntária, a despeito do amplo posicionamento doutrinário em sentido contrário.

Passados mais de 60 (sessenta) anos, o problema ainda é objeto de debates doutrinários, o que somente demonstra como Calmon de Passos enfrentou temas extremamente complexos sobre

\footnotetext{
1 Em homenagem quando do seu falecimento, destacou Antonio Adonias: Por todas essas obras, por sua atuação profissional e política, por sua carreira docente, pelo seu modo de ser e de estar no mundo, Calmon cumpriu o papel de espalhar benefícios nos caminhos que trilhou entre 16 de maio de 1920 e 18 de outubro de 2008, quando alçou à atemporalidade. Como ele mesmo dizia: "Nada é sozinho. Nada é para sempre. Todo saber é saber do homem, ser histórico e contingente, pelo que este saber só se legitima se apto para servir à humanidade”. BASTOS, Antonio Adonias Aguiar. Fora do círculo do tempo: Uma homenagem a Calmon de Passos. Disponível em: https://www.migalhas.com.br/depeso/289359/ fora-do-circulo-do-tempo-uma-homenagem-a-calmon-de-passos.
}

2 PASSOS, J. J. Calmon de. Da jurisdição. Salvador: Livraria Progresso, 1957. 
os institutos fundamentais do processo ${ }^{3}$, posicionando-se, em muitos casos, de forma contrária ao entendimento majoritário, a exemplo do seu estudo sobre a Ação no Direito Processual Civil Brasileiro, publicado em 1960.

Assim, o artigo pretende analisar a controvérsia acerca natureza da jurisdição voluntária, ainda que de forma sucinta.

\section{Da importância da jurisdição voluntária.}

A identificação da natureza jurídica da jurisdição voluntária consiste em problema histórico e objeto de estudos há muitos anos. A controvérsia pode ser evidenciada na Exposição de Motivos do Código de Processo Civil de 1973, em que Alfredo Buzaid expõe a dificuldade em sistematizar a jurisdição voluntária ${ }^{4}$ :

O quarto livro abrange procedimentos especiais, distribuídos em dois títulos: os de jurisdição contenciosa e os de jurisdição voluntária. Estará certa a colocação dos procedimentos de jurisdição voluntária no Livro IV? O tema tem sido objeto de larga controvérsia. No Direito alemão constitui objeto de lei especial (Gesetz über die Angelegenheiten der freiwilligen Gerichtsbarkeit de 17 de maio de 1898), modificada por leis posteriores. Mas nem a lei alemã abrange toda a jurisdição voluntária, nem o Código de Processo Civil se absteve completamente de tratar dela. Na Áustria, a lei de $1^{\circ}$ de agosto de 1895 , denominada Jurisdiktionsnorm, dedica o Capítulo III aos negócios não contenciosos (\$§ 105-122), mas de modo também incompleto.

Os autores, que trataram ex professo da matéria, reconhecem que a sistematização dos procedimentos de jurisdição voluntária está ainda por se fazer. LOPES DA COSTA, em monografia fundamental sobre o tema, diz que "sobre ela não temos lei especial. Dela, o Código de Processo Civil trata de envoltar com outros procedimentos especiais, de jurisdição contenciosa. Salvo a coisa julgada (artigo 288), não diz quais as normas gerais do processo que não se aplicam à jurisdição voluntária”.

O voto de NICETO ALCALÁ ZAMORA Y CASTILLO é de considerála objeto de lei especial, como na Alemanha; não sendo possível substituir a intervenção do juiz por notários, deveria figurar como apêndice ao Código de Processo Civil, com numeração própria.

JOSÉ FREDERICO MARQUES, que escreveu também uma obra clássica sobre o tema, afirma que "a administração pública dos interesses privados, nem mesmo quando se realiza através da jurisdição voluntária, está afeta, no que diz com a sua regulamentação, às leis processuais. Cabe ao Direito Processual apenas a forma e o modus faciendi dos atos forenses da atividade de jurisdição voluntária”.

No projeto figura a jurisdição voluntária como título especial no Livro IV, porque, por larga tradição, em tais casos sempre coube ao juiz a função de administrar os interesses privados.

Apesar de figurar nos debates doutrinários pelo menos desde a década de $1930^{5}$, é certo que as divergências ainda persistem entre aqueles que sustentam a natureza administrativa e aqueles que identificam o caráter jurisdicional da jurisdição voluntária ${ }^{6}{ }^{7}$.

3 Didier Jr., Fredie. Editorial 51. Disponível em: http://www.frediedidier.com.br/editorial/editorial-51/. Acesso em: $03 / 07 / 2020$.

4 https://www2.senado.leg.br/bdsf/bitstream/handle/id/177828/CodProcCivil\%201974.pdf?sequence=4. Acesso em 05/09/2020.

5 Leonardo Greco afirma: "a corrente mais tradicional, que é capitaneada justamente por Zanobini, atribui à jurisdição voluntária natureza administrativa. Daí o seu conceito de administração pública de interesses privados. A essa corrente se opôs outra, capitaneada a partir da década de 1930 por Carnelutti, que discordou do entendimento de que a jurisdição voluntária tivesse natureza administrativa e lhe atribuiu natureza de atividade jurisdicional”. Com base nas referidas informações, para fins de contextualização do problema, adotamos a década de 1930 como marco da controvérsia. GRECO, Leonardo. Instituições de processo civil, 5 ed. Rio de Janeiro: Forense, 2015, p. 94.

6 De acordo com Fredie Didier Jr. a "jurisdição voluntária é um daqueles assuntos clássicos da dogmática processual, que acirra os ânimos doutrinários, sobre o qual, depois de tanto tempo, é difícil saber o que de definitivo já se construiu. Já se disse, inclusive, que a jurisdição voluntária nem é jurisdição nem é voluntária. DIDIER JR., Fredie. Curso de direito processual civil, vl. 1. 22 ed. Salvador: Ed. Jus Podivm, 2020, p. 233

7 Identifica-se, ainda, a posição eclética sustentada por Elio Fazzalari, que considera a referida atividade estatual como própria e distinta da atividade administrativa ou jurisdicional. FAZZALARI, Ellio. Giurisdizione Volontaria. Enciclopedia del 
O estudo da jurisdição voluntária é extremamente relevante, por algumas razões.

Robson Renault Godinho destaca que "os procedimentos de jurisdição voluntária são de uso frequente na prática forense e não é incomum que constituam o único contato direto do jurisdicionado com a jurisdição estatal ${ }^{8}$ e que diversos avanços jurídicos ocorreram por intermédio da jurisdição voluntária, a exemplo da guarda compartilhada, da curatela parcial, do registro de multiparentalidade e relações homoafetivas, do reconhecimento do nome social, dentre outros.

A despeito da importância da jurisdição voluntária e da sua incidência no dia a dia forense, a doutrina questiona a indiferença com o que tema foi tratado nos últimos anos, como se sua atividade não tivesse sido abarcada pelos avanços do Estado de Direito e fosse submetida a um procedimento sem garantias constitucionais processuais ${ }^{9}$.

Neste aspecto, parece relevante uma observação de Calmon de Passos ${ }^{10}$ :

Direito e decisão e participação no processo decisório, em todas as suas fases (organização, instrumentalização, enunciação e efetivação) é um elemento constitutivo da dimensão democrática do Estado de direito, uma garantia para ao cidadão e um espaço real de liberdade e de efetiva autodeterminação, constitutivos, por seu turno, de uma cidadania efetiva. Dizemos mais: é a única forma de realizar os direitos fundamentais, bem como os que deles decorrem, como seus desdobramentos, tirando-os do mundo do "faz-de-conta" dos enunciados, para coloca-los no mundo real dos acontecimentos.

Esquecer tudo isso e proclamar, com palavras retumbantes, a necessidade de efetividade, de celeridade, de deformação e de diferenciação da tutela é, em verdade, atrair-se com a isca tentadora da carne fresca o pobre animalzinho para a armadilha. A democracia é mais do que discurso, é compromisso, é sentimento, é exigência de respeito à dignidade própria e à dignidade do outro, principalmente do outro, porque no cuidar do respeito à nossa dignidade todos somos por demais diligentes.

Assim, ao ensejo do centenário de Calmon de Passos, pareceu relevante expor a compreensão desse grande jurista sobre o tema. Não necessariamente pela necessidade de identificação da natureza jurídica da jurisdição voluntária, mas sim para fixação de que a submissão às garantias constitucionais do processo é algo que se impõe, independente da técnica processual aplicada na Tutela dos Direitos.

\section{Dos posicionamentos acerca da natureza jurídica da jurisdição voluntária e da visão sustentada por Calmon de Passos.}

O Direito "é um dos processos sociais de adaptação, como a Religião, a Moral, a Arte, a Economia, a Política e a Ciência ${ }^{11}$ ”. Trata-se de um fenômeno complexo, que possui total relação com a sociedade e seus valores, na medida em que exerce sobre aquela uma função ordenadora, diante de uma pauta de conduta, que deve ser levada em consideração pelas pessoas, que naturalmente coexistem e encontramse vinculadas, por intermédio das normas jurídicas.

Diritto, vol. XIX, 1970, pp. 330/31 apud GRECO, Leonardo. Jurisdição voluntária moderna. São Paulo: Dialética, 2003 , p. 17.

8 GODINHO, Robson Renault. Comentários ao Código de Processo Civil, volume XIV (arts. 719-770). São Paulo: Saraiva Educação, 2018, p. 19.

9 Parece-me que a razão do desinteresse assenta numa superficial e, talvez, inconsciente impressão de que nada de novo existe a ser revelado a respeito da voluntária, que sobrevive como patinho feio do Direito Processo Civil, que não merece maior atenção, porque a sua disciplina não teria sido substancialmente afetada pelos avanços do Estado de Direito e da ciência processual, nem mereceria qualquer reflexão tendente a aperfeiçoa-la ou a harmonizá-la às ideias da efetividade e do garantismo, porque ela corresponderia a uma atividade secundaria dos juízes, uma atividade anômala e complementar, sem a dignidade e a relevância da jurisdição contenciosa. Ademais, o papel assistência do juiz e o interesse público que parece subjacente em muitos desses procedimentos explicariam um certo vale-tudo, em que os fins justificariam os meios. GRECO, Leonardo. Jurisdição voluntária moderna. São Paulo: Dialética, 2003, p. 8.

10 PASSOS, José Joaquim Calmon de. Comentários ao Código de Processo Civil, 8a ed. Rio de Janeiro: Forense, 1998 , p. 14.

11 MIRANDA, Pontes de. Tratado da ação rescisória, Campinas: Bookseller, 1998, p. 25. 
Associado ao homem e à sociedade, o Direito apresenta a "estrutura temporal da historicidade"12", em razão de seu processo de adaptação relacionar-se com a evolução da sociedade e ao surgimento de novas circunstâncias fáticas, de modo que é fundamental que o Direito seja avaliado de acordo com o momento histórico e a fixação do poder político, para que seja possível avaliar "sua adequação quando aplicado à realidade social que procura ordenar ${ }^{13}$ ".

\section{Trata-se de aspecto relevante para compreensão da jurisdição voluntária.}

Em exercício de sua função ordenadora, o Direito estabelece que a constituição, modificação ou extinção de alguns atos da vida privada ou a produção dos seus efeitos somente ocorrerá após sua submissão ao ente estatal. Restringe-se, pois, a autonomia da vontade nas relações jurídicas privadas, tornando-se obrigatória a intervenção do Poder Judiciário em determinados atos privados, ainda que sem identificação de um conflito real ou potencial ${ }^{14}{ }_{-}^{15}$.

Verifica-se, aqui, uma atividade do Judiciário, que destoa de sua atividade primordial, ao menos à luz de um conceito tradicional de jurisdição, "como atividade substitutiva do juiz, cujo objeto é a eliminação de uma lide com força de coisa julgada em uma atividade plenamente vinculada a lei ${ }^{16 "}$.

Essa é a razão para a corrente clássica ou administrativista sustentar que a jurisdição voluntária não tem natureza de verdadeira jurisdição, sendo uma administração pública do direito privado ${ }^{17}$ exercida por órgãos judiciais, através de uma atividade de assistência e controle, conforme destacou Eurico Tullio Liebman ${ }^{18}$ e Piero Calamandrei ${ }^{19}$.

$\overline{12}$ LARENZ, Karl. Metodologia da Ciência do Direito, 6 ${ }^{\underline{a}}$ edição, Lisboa: Fundação Calouste Gulbenkian, 2012.

13 PASSOS, José Joaquim Calmon de. Revisitando o direito, o poder, a justiça e o processo. Salvador: Juspodivm, 2012 , p. 37.

14 A jurisdição voluntária é uma atividade estatal de integração e fiscalização. Busca-se do Poder Judiciário a integração da vontade, para torná-la apta a produzir determinada situação jurídica. Há certos efeitos jurídicos decorrentes da vontade humana, que somente podem ser obtidos após a integração dessa vontade perante o Estado-juiz, que o faz após a fiscalização dos requisitos legais para obtenção do resultado almejado. DIDIER JR. Fredie. Curso de direito processual civil, 22 ed. Salvador: Ed. Jus Podvm, 2020, p. 233.

15 Em sentido semelhante, afirma Leonardo Greco que “a jurisdição voluntária é uma modalidade de atividade estatal ou judicial, em que o órgão que a exerce tutela assistencialmente interesses particulares, concorrendo com o seu conhecimento ou com a sua vontade para o nascimento, a validade ou a eficácia de um ato da vida privada, para formação, o desenvolvimento, a documentação ou extinção de uma relação jurídica ou para eficácia de uma situação fática”. GRECO, Leonardo. Instituições de processo civil, 5 ed. Rio de Janeiro: Forense, 2015, p. 94.

16 MITIDIERO, Daniel Francisco. Elementos para uma teoria contemporânea do processo civil brasileiro. Porto Alegre: Livraria do Advogado editora, 2005, p. 75.

17 Segundo Leonardo Greco a denominação é do jurista italiano Guido Zanobini, que estudou o tema no Direito Administrativo. ZANOBINI, Guido. Corso di Diritto Amministrativo, $5^{\underline{o}}$ vol., $2^{\text {a }}$ ed. Giufrrè, Milano, 1957, pp. 293 e ss. José Frederico Marques também atribui a parternidade da denominação administração pública dos interesses privados a Guido Zanobini, mas faz referência a outro trabalho, publicado ainda em 1918. MARQUES, José Frederico. Ensaio sobre a Jurisdição

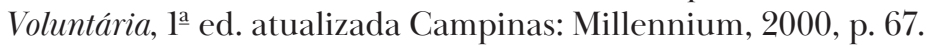

18 O enquadramento sistemático da jurisdição voluntária é muito controvertido, mas parecem ter razão os que a consideram em substância uma atividade administrativa, apesar de atribuída aos juízes e realizada mediante formas judiciais. Trata-se realmente, na maioria dos casos, de dispensar cuidado e proteção a determinados interesses privados, que são muito caros também ao Estado (p. ex., interesses dos menores de idade, dos doentes mentais etc.); para tanto, confia-se a um órgão público a tarefa de cooperar com os particulares na administração de tais interesses, supervisionando seus atos. O simples fato de sido atribuída a um juiz não é motivo suficiente para incluir essa atividade na jurisdição. Mais pertinente, por isso, parece a definição da jurisdição voluntária como administração pública de direito privado”. LIEBMAN. Eurico Tullio. Manual de Direito Processual Civil, vl. 1. São Paulo: Malheiros Editores, 2005, pp. $53 / 54$.

19 Na zona fronteiriça entre a função jurisdicional e administrativa, está a chamada jurisdição voluntária, a qual, mesmo sendo, como veremos a seguir, função substancialmente administrativa, é subjetivamente exercida por órgãos judiciais, e por isso é, designada, tradicionalmente, pelo nome equívoco de jurisdição, se bem acompanhado com o atributo de voluntária que tem a finalidade de distingui-la da verdadeira e própria jurisdição, da qual até agora se tem falado, e que, por sua vez, designa-se, em tal contraposição, como jurisdição contenciosa. Esta chamada jurisdição voluntária (que por acaso deriva seu nome tradicional da função, um tempo atribuída aos juízes, de documentar, como fazem hoje os escrivãos públicos, os acordos entre contratantes, inter volentes) constitui um dos caos mais típicos, já recordado mais acima, pelo qual, órgãos constituídos para exercer uma das três funções da soberania, exercem, por exceção, funções existentes. Aqui, no caso da jurisdição voluntária, os atos realizados pelo órgão judicial, que por razões subjetivas deveriam classificar-se de jurisdicionais, são administrativos por seu fim e por seus efeitos. Em substancia, a contraposição entre jurisdição voluntária e jurisdição contenciosa tem este significado: que só a jurisdição chamada contenciosa é jurisdição, enquanto a jurisdição 
Em 1952, José Frederico Marques apresentou seu Ensaio sobre a jurisdição voluntária ${ }^{20}$ visando a disputa da cátedra de "Direito Judiciário Civil" da Faculdade de Direitos da Pontifícia Universidade Católica de São Paulo. Seguramente, o referido estudo influenciou parcela significativa da doutrina brasileira acerca da natureza administrativa da jurisdição voluntária:

A natureza administrativa da jurisdição voluntária, admitida por grande número de doutrinadores, afigura-senos indiscutível. O Estado, quando intervém, através do juiz, para realizar as funções da denominada jurisdição voluntária, não atua com o intuito de fazer observar a ordem jurídica, nem para dirimir um litigio ou pretensão. Dessa forma, é evidente que a jurisdição voluntária nada tem de jurisdicional, porque os atos que se exigem para integrar ou alterar uma relação jurídica não se fundam em interesse de agir, consistente na necessidade da tutela por incerteza sobre uma relação jurídica, ou por lesão a direito individual.

Os atos de jurisdição voluntária não traduzem qualquer imposição do direito objetivo relativamente a uma pretensão, nem se destinam a dissipar incertezas e dúvidas a respeito da existência de relações de vida disciplinadas pela ordem jurídica. Quem requer do juiz uma providência de jurisdição voluntária, não o faz em função de uma lesão a direitos individuais, nem em razão das dúvidas que autorizam o pedido de um pronunciamento declaratório. A prestação estatal que é requerida ao órgão judiciário tem conteúdo bem diverso daquela que lhe é solicitada quando se invoca a tutela jurisdicional. Na jurisdição voluntária, a intervenção do juiz se faz imprescindível para que uma relação jurídica possa constituir-se ou modificar-se. O órgão judiciário presta sua assistência, integrando um negócio jurídico, e isto porque o Estado, apesar de tratar-se de relações de interesse individual, entende dever tutelá-las a fim de garantir melhor os preceitos legais que regem essas relações da vida.

Em matéria de jurisdição voluntária, não se pode, portanto, falar de jurisdição propriamente dita. O juiz, como lembra RENÉ MOREL, participa aí da administração civil; mas, como se trata de assegurar a proteção de interesses privados, os tribunais judiciários se encontram qualificados para o cumprimento dessa função, que, aliás, lhes vem atribuída também por força de tradição constante ${ }^{21}$.

Para José Frederico Marques, a jurisdição voluntária decorre de uma tradição histórica do direito romano, que reconhecia a conveniência de cercar de garantias de autenticidade certas manifestações da atividade individual e privada, mediante a intervenção dos magistrados. Visa prevenir lesões ou lides futuras e, portanto, evitar a "reduplicação do exercício das atribuições tutelares do Estado"2", possuindo exclusivamente o caráter de função judiciária, e não o de jurisdiciona $2^{23}$.

chamada voluntária não é jurisdição, senão que é administração exercida por órgãos judiciais”. CALAMANDREI, Piero. Direito Processual civil, v. 1. Campinas: Bookseller, 1999, p. 155-159.

20 MARQUES, José Frederico. Ensaio sobre a Jurisdição Voluntária, 1ํㅡ. ed. atualizada Campinas: Millennium, 2000.

21 MARQUES, José Frederico. Ensaio sobre a Jurisdição Voluntária, 1ae ed. atualizada Campinas: Millennium, 2000 , p. 65

22 Atribuindo ao Judiciário a atividade administrativa da jurisdição voluntária, quis o Estado evitar a reduplicação do exercício de suas atribuições tutelares, uma vez que, tratando-se de atos pertinentes a interesses individuais, a lei não poderia, caso estivessem afetos a órgãos administrativos, impedir o seu reexame pelo Judiciário, sempre que os funcionários do Poder Executivo, no exercício desses atos, não atendessem aos direitos e interesses daqueles que necessitassem da tutela administrativa do Estado. MARQUES, José Frederico. Ensaio sobre a Jurisdição Voluntária, 1ª ed. atualizada Campinas: Millennium, 2000, p. 72.

23 A construção doutrinaria de toda a obra de MICHELLI, sem dúvida brilhantíssima, peca por esse defeito capital de pretender transformar em jurisdicional uma atividade nitidamente administrativa, esquecido de que o traço subjetivo da intervenção do magistrado dá a jurisdição voluntária exclusivamente o caráter de função judiciária, e não o de jurisdicional. MARQUES, José Frederico. Ensaio sobre a Jurisdição Voluntária, 1ª ed. atualizada Campinas: Millennium, 2000, pp. 84-85; 87 
No mesmo sentido, à luz da concepção tradicional de jurisdição, Humberto Theodoro Júnior ${ }^{24}$ e outros autore ${ }^{25}$ afirmam que não há como se sustentar a natureza jurisdicional da jurisdição voluntária, destacando que aqueles que o fazem precisam inovar a própria definição tradicional (histórica) do que seja jurisdição.

Em síntese, a corrente clássica ou administrativista sustenta que na jurisdição voluntária não há lide e, por consequência: (i) não há processo e sim mero procedimento; (ii) não há partes e sim interessados, que buscam obter o mesmo bem da vida, ou seja, não existem duas pessoas em posições antagônicas, com interesses conflitantes; (iii)não há substitutividade, pois o atividade do juizé integradora e constitutiva; (iv) não existe aplicação do direito, pois o juiz chancela a vontade dos interessados; (v) não há coisa julgada material, sob o fundamento de que a sentença pode ser modificada diante de circunstâncias novas e supervenientes ${ }^{26}$.

Em contraponto à corrente administrativista, verifica-se a doutrina jurisdicionalista ${ }^{27}$, que sustenta a natureza jurisdicional da atividade desenvolvida pelo juiz em jurisdição voluntária.

Em 1957, quando Calmon de Passos publicou sua obra Da Jurisdição, o entendimento majoritário, quase dominante, caracterizava a jurisdição voluntária como uma administração pública do direito privado exercida por órgãos judiciais, em especial pela influência de Liebman e José Frederico Marques, expoentes da escola paulista de processo que, na década de 50, já haviam publicado trabalhos sobre o tema.

Todavia, a existência do referido entendimento dominante não foi suficiente para inibir a crítica realizada por Calmon de Passos e sustentar posicionamento em sentido contrário. Trata-se de traço marcante de sua produção intelectual de Calmon de Passos, como bem ressaltado por Fredie Didier Jr. ${ }^{28}$ em prefácio à reedição do livro A Ação no Direito Processual Civil Brasileiro. Apesar de ter por objeto

24 Se uma jurisdição é necessária na ordem constitucional de separação dos poderes soberanos do Estado (a “contenciosa”) e outra não é necessária para a função tutelar atribuída à justiça de que o poder se acha institucionalmente encarregado (a "voluntária"), como definir a jurisdição, nela inserindo papel meramente acidental, que tanto pode ser desempenhado por órgão judicial como por órgão administrativo? Se funcional e objetivamente as atividades desempenhadas no âmbito da jurisdição voluntária não são necessárias ao cumprimento das atividades fundamentalmente reservadas ao Poder Judiciário, e não são iguais às "necessárias", i.e., as que correspondem à jurisdição contenciosa, impossível atribuir a ambas uma só e mesma natureza. Ademais, que proveito prático, ou mesmo teórico, se pode esperar da absorção da jurisdição voluntária pelo conceito único de jurisdição, se, com tal conceito, não se logrará homogeneidade para o procedimento, o objetivo e a eficácia das tutelas prestadas nas duas "espécies” de jurisdição? O esforço teórico terá sido improdutivo e, por isso mesmo, sem relevância científica. A constatação inevitável é de que, pela própria complexidade e diversidade das medidas que se podem tomar sob o nomen iuris de "jurisdição voluntária”, sempre houve muita dificuldade de generalizar aquilo que constituiria a sua substância; e, consequentemente, confusa e incerta tem sido a missão dos que se empenham a traçar os seus limites. Muito mais seguro é conceituar a jurisdição, segundo a função necessária que a Constituição lhe destina, sem dúvida ligada à solução de conflitos (litígios), e deixar para a noção de “jurisdição voluntária tudo aquilo que, sem a presença da contenciosidade, é apenas acidentalmente atribuído aos órgãos jurisdicionais, num plano predominantemente administrativo. Não há como pensar, num universo de conteúdo tão variado e complexo, que a atividade da jurisdição contenciosa e a da jurisdição voluntária sejam espécies de um só gênero, quando tudo conspira a evidenciar que se trata de dois gêneros distintos de atividade". A só coincidência subjetiva do órgão que as exerce não tem o poder de anular a diversidade essencial de objeto e finalidade. THEODORO Júnior, Humberto. Curso de Direito Processual Civil - Vol. I, 60 edição. Rio de Janeiro: Forense, 2019, pp. 123/124. No mesmo sentido, BUENO, Cassio Scarpinella. Curso sistematizado de direito processual civil, vl. 1, 9ª ed., São Paulo: Saraiva Educação, 2018, p. 263.

25 DELlORE, Luiz et al. Teoria Geral do Processo Contemporâneo, $3^{\text {a }}$ edição. São Paulo: Atlas, 2016, p. 133: "Considerando esses aspectos, além do fato de a atuação do Judiciário nesses casos não ser constitucionalmente necessária, concordamos com a posição tradicional na doutrina brasileira de que a jurisdição voluntária não é jurisdição, revelando-se na verdade como administrativa”; BAHIA, Alexandre et al. Teoria Geral do Processo, Salvador: Editora JusPodivm, 2020, p. 143: "Já na Jurisdição Voluntária, nas palavras de Alcalá Zamora, estamos diante de um "não processo", pois a participação do Judiciário somente viabiliza a perfeição de uma atividade convergente das partes envolvidas. Nela o Judiciário assume funções administrativas - "gestão pública de interesses privados" - que, por sua importância, o legislador houve por bem estabelecer que certos atos jurídicos apenas se aperfeiçoam com a presença do juiz, mas sem que este substitua a vontade das partes à sua, como na jurisdição contenciosa”.

26 DIDIER JR. Fredie. Curso de direito processual civil, 22 ed. Salvador: Ed. Jus Podivm, 2020, pp. $239-244$.

27 Sustentada por Gian Antonio Micheli, J.J. Calmon de Passos, Ovídio A. Baptista da Silva, Daniel Francisco Mitidiero, Luiz Guilherme Marinoni, Fredie Didier Junior, Cândido Rangel Dinamarco, Robson Renault Godinho, entre outros.

28 Durante os anos 50, a ciência processual civil brasileira começou a desenvolver-se com mais rapidez e intensidade. Obras importantíssimas começaram a ser publicadas, em bom número e em diversos estados da federação. Esse "boom” 
outra obra, a análise reflete que Calmon de Passos nunca foi um jurista adepto à reprodução de ideais acriticamente, o que também não ocorreu em sua análise sobre a jurisdição e, em especial, sobre a natureza jurídica da jurisdição voluntária, refutada pela a esmagadora maioria dos processualistas da época.

Partindo do conceito de jurisdição como "a aplicação autoritativa da lei, mediante a substituição por uma atividade pública da atividade alheia 29 " e após analisar as características dos atos administrativos, Calmon de Passos afirma que a corrente administrativista se sustenta em visão preconceituosa da jurisdição, limitando-a ao âmbito contencioso, o que não pode ser aceito:

(...) a tutela jurídica do sujeito não se esgota só com o garantir-se a êle o direito de ação; nem a intervenção dos órgãos jurisdicionais visa unicamente eliminar os conflitos de interesses e a satisfação coativa desses mesmos interesses. Ao lado desta forma de tutela que dá lugar à chamada jurisdição contenciosa, existe uma outra forma mais imediata, porque não pressupõe nenhum conflito e muito menos nenhuma violação de direito, mas que se exercita diretamente com vistas à situação jurídica dos sujeitos, tanto para sua constituição, como para sua modificação ou extinção.

Esta tutela não tem, como a contenciosa, caráter geral, porque isso entraria em choque com o princípio da autonomia negocial. Ela apenas existe quando a lei expressamente põe com seus determinados interesses individuais, ou subordina a manifestação da autonomia negocial, com relação a determinados interesses, postos como gerais pela norma. Nestes casos ela tutela êsses interesses ou impondo a constituição de determinadas situações jurídicas, ou submetendo a contrôle, preventivo ou sucessivo, os atos que constituem ou que a modificam. Essa tutela, confiada aos órgãos jurisdicionais, constitui a chamada jurisdição voluntária, que é verdadeira e própria jurisdição.

Ato contínuo, em relação à alegação de que não existe aplicação do direito na jurisdição voluntária, pois o juiz apenas chancelaria a vontade dos interessados, Calmon de Passos destacou que "em senso lato um juris dicere existe tanto na jurisdição voluntária quanto na contenciosa, porque em ambas o juiz declara o direito, seja quando resolve uma controvérsia entre dois sujeitos, seja quando apenas autoriza um indivíduo a agir de um determinado modo. A violação da ordem jurídica não é um pressuposto dessa atividade jurisdicional, como não o é também nas ações meramente declaratórias. Entretanto nunca se negou o caráter jurisdicional da providencia que se dita nas ações meramente declaratórias".

Portanto, para Calmon de Passos "como os atos de jurisdição contenciosa, os atos de jurisdição voluntária também atuam o direito objetivo, só que essa atuação, em lugar de efetivar-se em gente a um conflito de interesses, realiza-se com a constatação da conformidade de uma determinada situação com os superiores interesses que o legislador teve em mira resguardar ${ }^{30 "}$.

Calmon de Passos refuta a alegação de que não haveria substitutividade na jurisdição voluntária, pois o juiz, quando integra a vontade dos particulares a "elas se substitui, quando se acham ausentes ou incapazes; concorre para formação de uma situação jurídica que deve cuidar para que corresponda

intelectual deve-se, muito, como se base, à presença de Enrico Tullio Liebman, no Brasil dos anos 40, ministrando aulas no Rio de Janeiro e, sobretudo, em São Paulo, onde fez escola. A importância de Liebman para o desenvolvimento da ciência processual civil brasileira é indiscutível. A maior prova dessa influencia talvez seja o Código de Processo Civil brasileiro de 1973, publicado quase trinta anos após a passagem de Liebman pelo Brasil, mas que traz em seu conteúdo as marcas do pensamento do professor de Milão - o regime jurídico proposto as condições da ação sobressai como principal sinal desta influencia. Para boa parte dos processualistas brasileiros que surgiram após os anos 50, Liebman foi o grande mestre e as suas obras, os principais referenciais teóricos. Neste contexto histórico, Calmon, um então desconhecido promotor de justiça baiano, resolve concorrer à cátedra de Direito Judiciário Civil (antiga designação da disciplina Direito Processual Civil) na Faculdade de Direito da Universidade Federal da Bahia. Escolhe, como tema da sua tese, um dos núcleos do pensamento liebmaniano: a concepção sobre o direito de ação e o seu peculiar entendimento sobre as condições da ação. Em vez do caminho mais fácil da louvação - seguindo ou, no máximo, desenvolvendo o pensamento de Liebman, já consagrado no Brasil -, Calmon optou pelo enfrentamento: o propósito da tese, como o leitor poderá ver, é demolir o arcabouço teórico do pensamento de Liebman sobre o direito de ação e, especialmente, sobre as condições de ação. DIDIER JR, Fredie. Prefacio à Reedição. PASSOS, J.J. Calmon. Ação no direito processual civil brasileiro. Salvador: Editora JusPodivm, 2013.

29 PASSOS, J. J. Calmon de. Da jurisdição. Salvador: Livraria Progresso, 1957, p. 31.

30 PASSOS, J. J. Calmon de. Da jurisdição. Salvador: Livraria Progresso, 1957, p. 53. 
à finalidade que a lei se propõe. Age tendo mais em vista razões de conveniência e oportunidade que motivos de estrita legalidade. Decidindo êle não ordena, mas autoriza ${ }^{31}$ ".

Em sua análise, Calmon de Passos também afirmou que não é verdadeira a alegação de que somente na jurisdição contenciosa existiria coação ou possibilidade de coação, o que não se verificaria na jurisdição voluntária, destacando que "pode o juiz coagir o interessado", o tutor, a exercer a tutela, por exemplo ${ }^{32}$.

Visando desconstruir o posicionamento dominante, Calmon de Passos afirmou que a natureza jurisdicional também não pode ser refutada com apoio em aspectos formais, "pois o legislador não distinguiu os processos voluntários dos processos contenciosos limitando-se a apenas a dizer que as decisões naqueles proferidas não fariam coisa julgada”.

Por fim, sobre a alegação de que não haveria coisa julgada material, afirma Calmon de Passos não ser possível se valer de tal característica para distinguir as duas espécies de jurisdição "porquanto se precisa saber, antes, quando elas são voluntárias, para que se verifiquem as consequências e não partir das consequências para se afirmar a natureza voluntária da jurisdição ${ }^{33}$ ".

Ainda que não se concorde com todas as premissas expostas por Calmon de Passos, é certo que suas considerações demonstram um Autor destemido e que não aceitava a mera reprodução do pensamento então dominante.

O posicionamento de Calmon de Passos floresceu e atualmente é seguido por diversos doutrinadores, que sustentam a natureza jurisdicional da jurisdição voluntária, pois "fruto de um sujeito estatal, dotado de império, investido em garantias funcionais que lhe outorguem imparcialidade e independência, cuja função é aplicar o direito (e não apenas a lei) de forma especifica, dotado o seu provimento de irreversibilidade externa ${ }^{34}$ ".

Cândido Rangel Dinamarco sustenta que a atividade desenvolvida pelo juiz caracterizada como jurisdição voluntária consiste em "autèntico exercício de jurisdição". Afirma que "no estado atual da ciência do processo a afirmação de que a jurisdição voluntária não é jurisdição nem voluntária não passa de um gracejo destoante dos conceitos hoje aceitos". Destaca-se, contudo, que Dinamarco adota uma compreensão mais restritiva, refutando as razões metodológicas que justificam a inclusão das atividades receptícias ou certificantes no conceito de jurisdição voluntária ${ }^{35}$.

Leonardo Greco apresenta extenso estudo sobre a jurisdição voluntária, apontando as diferentes visões sobre a sua natureza jurídica. Ao final, o referido jurista apresenta seu posicionamento ${ }^{36}$ :

Em síntese, penso que a administração pública do Direito Privado, ou a jurisdição voluntária, é administrativa quando exercida por órgãos da administração pública sem as garantias de independência, impessoalidade e imparcialidade, jurisdicional quando exercida pelos juízes e por quaisquer órgãos judiciais ou extrajudiciais que as exerçam com as referidas garantias, e quase jurisdicional quando exercida por serventuários da justiça sob a direta disciplina e fiscalização dos juízes.

Não é jurisdicional simplesmente porque exercida por juízes, mas é jurisdicional por causa das características de que se reveste o exercício da função jurisdicional, que asseguram que a tutela do interesse privado tenha por

31 PASSOS, J. J. Calmon de. Da jurisdição. Salvador: Livraria Progresso, 1957, p. 53-54.

32 PASSOS, J. J. Calmon de. Da jurisdição. Salvador: Livraria Progresso, 1957, p. 56.

33 PASSOS, J. J. Calmon de. Da jurisdição. Salvador: Livraria Progresso, 1957, p. 57.

34 MITIDIERO, Daniel Francisco. Elementos para uma teoria contemporânea do processo civil brasileiro. Porto Alegre: Livraria do Advogado editora, 2005, p. 80. Para Mitidiero, "postas essas coordenadas a respeito do conceito contemporâneo de jurisdição, cumpre referir que a jurisdição voluntária, que no conceito tradicional de jurisdição não se identificava com a mesma, sendo considerada mera administração pública de interesses privados, consoante já declinamos noutro lugar, reveste natureza jurisdicional, não diferindo da jurisdição contenciosa senão pela ausência de conflito entre as partes. A doutrina contemporânea tende a confluir no entendimento de que a jurisdição voluntária ensarta-se nos quadros da autentica jurisdicional”.

35 DINAMARCO, Cândido Rangel. Instituições de direito processual civil, vl. 1. 10 ed. São Paulo: Malheiros, 2020, pp. 409-

410.

36 GRECO, Leonardo.Jurisdição voluntária moderna. São Paulo: Dialética, 2003, p. 20-21. 
escopo a elaboração de juízos discricionários ou vinculados ou o exercício de alguma outra atividade ditados exclusivamente no interesse dos próprios destinatários.

O Estado não precisa da tutela do Judiciário. Quando a atividade do Estado é submetida à aprovação judicial, isso ocorre para garantir que ela se desenvolva com o mais rigoroso respeito aos direitos e à liberdade dos cidadãos. É para proteger esses direitos e tutelar os interesses dos particulares que a lei confere aos juízes a solução dos litígios e a administração de outras situações e relações jurídicas que, por sua relevância para os próprios titulares, devem formar-se ou desenvolver-se com a vigilância direta do Poder Público.

A jurisdição voluntária é atividade assistencial do Estado. Ele não a exerce em seu benefício, mas em benefício da convivência pacífica e harmoniosa de todos os cidadãos através da justa proteção dos seus interesses.

Em trabalho recente, Robson Renault Godinho afirma que "a jurisdição voluntária possui natureza jurisdicional e pode ser voluntária, de acordo com as escolhas legislativas acerca de determinado assunto $^{37}$.

Fredie Didier Jr., expõe de forma detalhada os contrapontos que fundamentam a jurisdição voluntária como atividade jurisdicional: (i) a jurisdição voluntária não pressupõe a lide, mas não significa que ela não exista ${ }^{38}$; (ii) a jurisdição voluntária também é inevitável e é atividade exercida por juízes com todas as garantias constitucionais da magistratura; (iii) o processo é categoria que pertence a teoria geral do direito ${ }^{39}$, sendo que a jurisdição voluntária também é exercida mediante procedimento em contraditório; (iv) a jurisdição voluntária é exercida por um terceiro imparcial e desinteressado, para atender interesses privados, o que não ocorre no exercício da atividade administrativa; v) se há processo, não há que se negar a existência da jurisdição, da ação, das partes em sentido processual, etc; vii) a decisão proferida em sede de jurisdição voluntária tem aptidão a formação da coisa julgada ${ }^{40}$

Por tais razões, Luiz Guilherme Marinoni, Sérgio Cruz Arenhart e Daniel Mitidiero ${ }^{41}$ afirmam que "a distinção nos termos em que posta na doutrina clássica não tem qualquer razão de ser atualmente. Na jurisdição voluntária há interpretação e aplicação do direito e há oferta de decisões revestidas de autoridade institucional, isto é, dotadas de definitividade e irrevisibilidade, tanto quanto na jurisdição contenciosa".

\section{Da compreensão atual da jurisdição.}

Ainda que não seja objeto central do presente artigo, verifica-se que a divergência acerca da natureza jurisdicional da jurisdição voluntária perpassa pelas diversas compreensões da própria jurisdição, pautadas em concepções de Estado distintas, moldadas pelo surgimento de novas circunstâncias fáticas e novos direitos e, por consequência, de uma tutela jurídica correlata a essa nova realidade social ${ }^{42}$.

37 GODINHO, Robson Renault. Comentários ao Código de Processo Civil, volume XIV (arts. 719-770). São Paulo: Saraiva Educação, 2018, p. 23.

38 Embora sustenta a ausência de natureza jurisdicional, Hugo Nigro Mazzilli reconhece que: "embora na jurisdição voluntária não se fale tecnicamente em lide, nela se admite haver controvérsia, na decisão da qual deve o Magistrado, de regra, manter seu equilíbrio, sem conduzir de ofício a apuração dos fatos. Para atingir esse escopo, em regra na jurisdição voluntária se confere não só o poder de impulso, como se impõe a intervenção ao Ministério Público (art. 1104 do CPC)”. MAZZILLI, Hugo Nigro Revista de Processo, n. 48, ano 12, out-dez 87, p. 217, ed. Rev. Dos Tribunais, São Paulo.

39 Esse também é o entendimento de Calmon de Passos: "Na teoria geral do direito, a palavra "processo" tem abrangência maior. Deve ela incluir os modos pelos quais o direito disciplina sua própria criação. Há, assim, um processo legislativo, que edita normas de caráter geral, ao lado dos processos de criação de normas particulares: o negocial (criação da norma pelos próprios sujeitos interessados), o administrativo e o jurisdicional, formas autoritativas de edição de normas particulares, caracterizando-se o jurisdicional por ser criação de norma mediante atividade substitutiva (super partes e intra petitum). PASSOS, José Joaquim Calmon de. Comentários ao Código de Processo Civil, 8ª ed. Rio de Janeiro: Forense, 1998, p. 4

40 DIDIER JR. Fredie. Curso de direito processual civil, 22 ed. Salvador: Ed. Jus Podivm, 2020, pp. $239-244$.

41 MARINONI, Luiz Guilherme; ARENHART, MITIDIERO, Daniel. Curso de Processo Civil, $5^{\circ}$ ed. São Paulo: Thomson Reuters Brasil, 2020.

42 O tema foi abordado em outro trabalho do Autor. Tavares Júnior, Eraldo Ramos. Acesso à justiça e Macrolides. Disponível em: https://repositorio.ufba.br/ri/handle/ri/17473. 
O Estado Liberal adotou, como premissa, o princípio da legalidade, que acabou "por constituir um critério de identificação do direito; o direito estaria apenas na norma jurídica, cuja validade não dependeria de sua correspondência com a justiça, mas somente de ter sido produzida por autoridade dotada de competência normativa ${ }^{43}$ ". A vinculação do Direito à lei, a cargo do Parlamento, também respaldava a compreensão da atuação dos demais Poderes. Neste sentido, no entendimento liberal e positivista, o papel do juiz seria de simples intérprete e aplicador da lei, inexistindo atividade criativa no ato de julgar, senão de afirmação daquilo que havia sido imposto pelo legislativo.

Essa submissão do juiz à lei, bem como a igualdade formal, a separação dos poderes e a liberdade individual compõem a realidade político-sócio-econômico da época e explicam as sucessivas concepções de jurisdição no Estado Liberal, seja como a atuação repressiva e protetiva dos direitos subjetivos privados, seja como a atuação da vontade concreta da lei, de Chiovenda, ${ }^{44}$ ou, ainda, como a justa composição da lide, defendida por Carnelutti ${ }^{45}$.

À luz dessas concepções de jurisdição, a doutrina administrativista refuta a natureza jurisdicional da jurisdicional voluntária, conforme entendimento de José Frederico Marques e Humberto Theodoro, no sentido que não há como se sustentar a natureza jurisdicional da jurisdição voluntária, destacando que aqueles que o fazem precisam inovar a própria definição tradicional (histórica) do que seja jurisdição.

Diferentemente do Estado Liberal, de perfil eminentemente individualista e privatista, o Estado contemporâneo e suas constituições dirigentes, permeadas pelos direitos fundamentais, realçaram a existência de direitos metaindividuais, que extrapolam os simples limites intersubjetivos.

A evolução do processo histórico do Estado liberal ao Contemporâneo tem estreita relação com a compreensão da teoria dos princípios, com o desenvolvimento dos direitos fundamentais, representantes de um sistema de valores contidos na Constituição e pelo controle de constitucionalidade, como um dos mecanismos de controle da compatibilidade dos atos normativos infraconstitucionais em relação à Constituição, para assegurar a unidade do sistema jurídico ${ }^{46}$.

Neste sentido, a visão do juiz como mero aplicador da lei deixa de ser adequada à compreensão da jurisdição do Estado contemporâneo, na medida em que o juiz atua como um recriador do Direito, analisando a lei à luz da Constituição e, se for o caso, promovendo "os devidos ajustes para suprir as suas imperfeições ou encontrar uma interpretação adequada, podendo chegar a considerá-la inconstitucional no caso em que a sua aplicação não é possível diante dos princípios de justiça e dos direitos fundamentais ${ }^{47}$ ".

43 MARINONI, Luis Guilherme. Curso de processo civil, volume 1: teoria geral do processo, São Paulo: Editora Revista dos Tribunais, 2006, p. 25.

44 CHIOVENDA define a jurisdição como a função do Estado que tem por escopo a atuação da vontade concreta da lei por meio da substituição, pela atividade de órgãos públicos, da atividade de particulares ou de outros órgãos públicos, já no afirmar a existência da vontade da lei, já no torná-la, praticamente, efetiva. CHIOVENDA, Giuseppe. Instituições de direito processual civil. Vol. II, Campinas: Bookseller, 2000, p. 8.

45 Afirma CARNELUTTI: "Quer dizer que o conflito atual supõe a prática de um ato por cada um dos sujeitos, os quais, ao praticá-lo, se tornam dois contendores: um deles pretende e o outro resiste à pretensão. A ciência do direito processual submeteu este fenômeno a uma análise senão definitiva, pelo menos muito adiantada, e elaborou os conceitos da pretensão e da resistência, respectivamente como exigência da prevalência de um interesse próprio sobre o interesse alheio, e como oposição a tal exigência. Ao conflito de interesses, quando se efetiva com a pretensão ou com a resistência, poderia dar-se o nome de contenda, ou mesmo controvérsia. Pareceu-me mais conveniente e adequado aos usos da linguagem o de lide”. CARNELUTTI, Francesco. Teoria Geral do Direito, São Paulo: LEJUS, 1999, p. 108. Segundo Luiz Guilherme Marinoni, "Carnelutti atribuiu à jurisdição a função de justa composição da lide, entendida como conflito de interesses qualificado pela pretensão de um e pela resistência do outro interessado. A lide, no sistema de Carnelutti, ocupa o da ação no sistema chiovendiano". MARINONI, Luis Guilherme. Curso de processo civil, volume 1: teoria geral do processo, 7 ed. São Paulo: Editora Revista dos Tribunais, 2013, p. 35.

46 BARROSO, Luís Roberto. O controle de constitucionalidade no direito brasileiro: exposição sistemática da doutrina e análise crítica da jurisprudência, 6 ed., São Paulo: Saraiva, 2012, p. 23.

47 MARINONI, Luis Guilherme. Curso de processo civil, volume 1: teoria geral do processo, 7 ed. São Paulo: Editora Revista dos Tribunais, 2013, p. 54. 
Vale-se, para tanto, dos princípios como forma de analisar a constitucionalidade da lei, como premissa para interpretação das leis ou como fonte de colmatação do Direito, diante da ausência de regras. Portanto, os princípios possuem uma função interpretativa, integrativa, definidora e bloqueadora.

Logo, trata-se de mudança radical na noção da atividade desempenhada pelo juiz, na possibilidade de construção/reconstrução da norma jurídica "a partir da interpretação de acordo com a Constituição, do controle da constitucionalidade e da adoção da regra do balanceamento (ou da regra da proporcionalidade em sentido estrito) dos direitos fundamentais no caos concreto ${ }^{48}$ ".

Com base neste novo contexto histórico, fruto de mudanças da própria compreensão de Estado, Fredie Didier Jr. sustenta seu conceito de jurisdição ${ }^{49}$ :

A jurisdição é a função atribuída a terceiro imparcial (a) de realizar o Direito de modo imperativo (b) e criativo (reconstrutivo) (c), reconhecendo/efetivando/protegendo situações jurídicas (d) concretamente deduzidas (e), em decisão insuscetível de controle externo (f) e com aptidão para tornar-se indiscutível (g).

Esse conceito é o que parece estar de acordo com as diversas transformações pelas quais passou o Estado nos últimos tempos. Não é mais possível utilizar a noção de jurisdição criada para um modelo de Estado que não mais existe, notadamente em razão de diversos fatores, tais como: i) a redistribuição das funções do Estado, com a criação de agencias reguladoras (entes administrativos, com funções executivas, legislativa e judicante) e executivas; ii) a valorização e o reconhecimento da força normativa da Constituição, principalmente das normasprincípio, que exigem do órgão jurisdicional uma postura mais ativa e criativa para a solução dos problemas; $i i i$ o desenvolvimento da teoria jurídica dos direitos fundamentais, que impõe a aplicação direta das normas que os consagram, independentemente de interminação legislativa; $i v)$ a criação de instrumentos processuais como o mandado de injunção, que atribui ao Poder Judiciário a função de suprir, para o caso concreto, a omissão legislativa; v) a alteração da técnica legislativa: o legislador contemporâneo tem-se valido da técnica das cláusulas gerais, deixando o sistema normativo mais aberto e transferindo expressamente ao órgão jurisdicional a tarefa de completar a criação da norma jurídica do caso concreto; vi) a evolução do controle de constitucionalidade difuso, que, dentre outras consequências, produziu entre nós a possibilidade de enunciado vinculante da súmula do STF em matéria constitucional, texto normativo de caráter geral, a despeito de ter sido produzido pelo Poder Judiciário.

A necessidade de compreensão da jurisdição à luz das novas funções que o Judiciário é chamado a exercer no Estado de Direito contemporâneo também foi abordado por Antonio do Passo Cabral em Per um nuоvo conceito di giurisdizione, artigo escrito em homenagem a Nicola Picardi ${ }^{50}$.

48 MARINONI, Luis Guilherme. Precedentes Obrigatórios. São Paulo: Editora Revista dos Tribunais, 2010 , pp. 90-91.

49 DIDIER JR. Fredie. Curso de direito processual civil, 22 ed. Salvador: Ed. Jus Podivm, 2020, pp. 193-194

50 CABRAL, Antônio do Passo. Per um nuovo concetto di giurisdizione. Disponível em https://www.academia. edu/42680672/Per un nuovo concetto di giurisdizione. De acordo com o Autor o conceito de jurisdição não reflete a gama de funções que os órgãos judiciais são instados a exercer no Estado de Direito contemporâneo, destacando: $i$ ) a necessidade de reconhecimento dos equivalentes jurisdicionais, como outras formas de resolução de conflitos na sociedade. O mais importante não é a figura do Estado e sim um procedimento com garantias processuais, conduzido por um terceiro imparcial; ii) ao longo dos anos, o conceito de jurisdição ficou atrelado à dicotomia privatismo e publicismo. Todavia, tais interesses devem coexistir e não serem tratados como mutuamente exclusivos. Admitir a relevância dos interesses privados no processo, ou conceber a proteção de situações jurídicas subjetivas como uma finalidade da jurisdição, não significa um retorno ao privatismo romano, nem levaria à eliminação do Estado, que integra necessariamente a relação processual; iii) não se concebe mais a jurisdição, como atividade do Estado para solução do conflito de forma retrospectiva. O Estado assumiu novo papel, de indutor de comportamentos, e, neste sentido, a jurisdição passa a também ser prospectiva, tendo abordagem para o futuro. A atuação da jurisdição na gestão da segurança jurídica e a necessidade de fixação de regras transitória em caso de superação das estabilidades processuais é um exemplo desse novo âmbito de atuação da jurisdição; iv) é um equívoco considerar que toda atividade jurisdicional é exercida em caráter substitutivo a vontade das partes em disputas, o que não acontece quando o Ministério Público requer a absolvição do réu, por exemplo. Destaca, ainda, o fomento a autocomposição e a maior atribuição de poderes aos litigantes, que podem celebrar convenções processuais que serão aplicadas ao caso em julgamento; vi) a concepção atual da teoria das normas afasta a concepção de que a jurisdição é meramente declaratória, exercendo também certo papel criativo, na construção e reconstrução da regra no processo de interpretação e aplicação. Tal característica também é evidenciada no papel da jurisprudência como fonte de direito. A função declaratória dos direitos não esgota as funções jurisdicionais, conforme se verifica nos procedimentos probatórios preparatórios, em que visam evitar litigio mediante a revelação fática (art. 381, do CPC), bem como eventual função 
Assim, em que pese não se poder afirmar que as mudanças ocorreram isoladamente ou da mesma forma em todos os sistemas jurídicos, é certo que representa uma mudança de compreensão da jurisdição e, portanto, tem que ser apreendida pelo operador do direito, que procura compreender a realidade atual.

\section{Conclusões}

O presente artigo não tem a pretensão de esgotar o debate sobre a natureza jurídica da jurisdição voluntária, mas ressaltar a importância da doutrina de Calmon de Passos, um jurista que nunca foi adepto a reprodução de ideais acriticamente, o que também não ocorreu em sua análise sobre a jurisdição e, em especial, sobre a natureza jurídica da jurisdição voluntária, refutada pela a esmagadora maioria dos processualistas da época.

Ainda que não se concorde com todas as premissas sustentadas por Calmon de Passos, é certo que o respeito às garantias constitucionais do processo é uma premissa irrefutável, em qualquer exercício de Poder, não sendo diferente na jurisdição voluntária.

\section{Referências}

BAHIA, Alexandre et al. Teoria Geral do Processo, Salvador: Editora JusPodivm, 2020

BARROSO, Luís Roberto. O controle de constitucionalidade no direito brasileiro: exposição sistemática da doutrina e análise crítica da jurisprudência, 6 ed., São Paulo: Saraiva, 2012

BASTOS, Antonio Adonias Aguiar. Fora do círculo do tempo: Uma homenagem a Calmon de Passos. Disponível em: https://www.migalhas.com.br/depeso/289359/fora-do-circulo-do-tempo-umahomenagem-a-calmon-de-passos

BUENO, Cassio Scarpinella. Curso sistematizado de direito processual civil, vl. 1, 9a ed., São Paulo: Saraiva Educação, 2018, p. 263.

CABRAL, Antônio do Passo. Per um nuovo concetto di giurisdizione. Disponível em https://www. academia.edu/42680672/Per un nuovo concetto di giurisdizione. Acesso em 02/09/2020

CALAMANDREI, Piero. Direito Processual civil, v. 1. Campinas: Bookseller, 1999. p. 155-159

CARNELUTTI, Francesco. Teoria Geral do Direito, São Paulo: LEJUS, 1999.

CHIOVENDA, Giuseppe. Instituições de direito processual civil. Vol. II, Campinas: Bookseller, 2000,

DELLORE, Luiz et al. Teoria Geral do Processo Contemporâneo, 3aㅡ edição. São Paulo: Atlas, 2016, p. 133.

DIDIER JR., Fredie. Curso de direito processual civil, vl. 1. 22 ed. Salvador: Ed. Jus Podivm, 2020, p. 233.

. Editorial 51. Disponível em: http://www.frediedidier.com.br/editorial/editorial-51/. Acesso em: 03/07/2020.

. Prefacio à Reedição. PASSOS, J.J. Calmon. Ação no direito processual civil brasileiro.

Salvador: Editora JusPodivm, 2013.

DINAMARCO, Cândido Rangel. Instituições de direito processual civil, vl. 1. 10 ed. São Paulo: Malheiros, 2020, p. 409-410

. A Instrumentalidade do Processo, 15 ed. São Paulo: Malheiros, 2013, p. 146.

consultiva da jurisdição, como ocorre na justiça eleitoral Brasileira; vii) deve-se compreender que a coisa julgada não é uma característica essencial da jurisdição, nem tampouco a única forma de estabilidade das decisões judiciais. 
GODINHO, Robson Renault. Comentários ao Código de Processo Civil, volume XIV (arts. 719-770). São Paulo: Saraiva Educação, 2018, p. 19.

GRECO, Leonardo. Instituições de processo civil, 5 ed. Rio de Janeiro: Forense, 2015, p. 94. Jurisdição voluntária moderna. São Paulo: Dialética, 2003, p. 8.

LARENZ, Karl. Metodologia da Ciência do Direito, 6ª edição, Lisboa: Fundação Calouste Gulbenkian, 2012.

LIEBMAN. Eurico Tullio. Manual de Direito Processual Civil, vl. 1. São Paulo: Malheiros Editores, 2005, pp. $53 / 54$.

MARQUES, José Frederico. Ensaio sobre a Jurisdição Voluntária, 1ํㅡㄹ ed. atualizada Campinas: Millennium, 2000.

MARINONI, Luis Guilherme. Curso de processo civil, volume 1: teoria geral do processo, São Paulo: Editora Revista dos Tribunais, 2006, p. 25. . Luis Guilherme. Precedentes Obrigatórios. São Paulo: Editora Revista dos Tribunais, 2010

MARINONI, Luiz Guilherme; ARENHART, MITIDIERO, Daniel. Curso de Processo Civil, $5^{\circ}$ ed. São Paulo: Thomson Reuters Brasil, 2020.

MAZZILLI, Hugo Nigro Revista de Processo, n. 48, ano 12, out-dez 87, p. 217, ed. Rev. Dos Tribunais, São Paulo.

MITIDIERO, Daniel Francisco. Elementos para uma teoria contemporânea do processo civil brasileiro. Porto Alegre: Livraria do Advogado editora, 2005.

MIRANDA, Pontes. Tratado de ação rescisória. Campinas: Bookseller, 1988, p. 302. . Tratado de Direito Privado, I, Rio de Janeiro: Borsói, 1954.

PASSOS, J. J. Calmon de. Da jurisdição. Salvador: Livraria Progresso, 1957. . Comentários ao Código de Processo Civil, 8ª ed. Rio de Janeiro: Forense, 1998. . Revisitando o direito, o poder, a justiça e o processo. Salvador: Juspodivm, 2012.

TAVARES JÚNIOR, Eraldo Ramos. Acesso à justiça e Macrolides. Disponível em: https://repositorio. ufba.br/ri/handle/ri/17473.

THEODORO Júnior, Humberto. Curso de Direito Processual Civil - Vol. I, 60 edição. Rio de Janeiro: Forense, 2019 